\title{
Fine Gravel Analyses after the Dutch Method as Tested out on Ristinge Klint, Denmark
}

\author{
JÜRGEN EHLERS
}

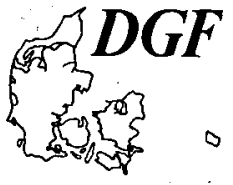

\begin{abstract}
Ehlers, J.: Fine Gravel Analyses after the Dutch Method as Tested out on Ristinge Klint, Denmark. Bull. geol. Soc. Denmark, vol. 27, pp. 157-165, Copenhagen, March 23rd, 1979. https://doi.org/10.37570/bgsd-1978-27-14

The Dutch-type fine gravel analysis has been tested as a stratigraphic tool in Quaternary studies. After having obtained good results, in Hamburg and in the adjoining parts of North Germany, the author analysed some samples from Ristinge Klint, in order to test whether this method could be used to answer stratigraphical questions in the area of the Weichselian glaciation as well. The analyses proved that one out of three exposed tills can be distinguished from the two others because of its fine gravel composition. Thus the fine gravel analysis may be of some use for Danish stratigraphers as well.
\end{abstract}

Jürgen Ehlers, Geologisches Landesamt Hamburg, Oberstr. 88, D-2000 Hamburg 13, West Germany. November 16th, 1978.

The Dutch type of fine gravel analysis includes a petrographic study of the 3-5 $\mathrm{mm}$ fraction in order to supply information as to the provenience and source areas for fluvial, fluvioglacial and glacial deposits. This method forms an important instrument in the study of the Quaternary deposits in the Netherlands, where repeated changes have occurred in the transport directions since the Tertiary (Maarleveld 1956, Zandstra 1959, 1971, 1975 and 1976). During the Tertiary and Early Pleistocene transport mainly took place via the rivers Rhine and Meuse. The early glaciations caused the German rivers to divert, and material of eastern origin, characterised by prophyries and lydite from the Thuringian Forest, reached the Netherlands. This situation was succeeded by sedimentation of glacial and fluvioglacial deposits rich in Scandinavian material and flint. As in the Netherlands until now Elsterian till was only found as a thin layer, in a single boring south of the island of Terschelling (Zandstra 1977), only tills of the Drenthe stage of the Saalian could be investigated. This stage is represented by several types of basal tills that differ both in general appearance and in their fine gravel composition (Zandstra 1976, 1978).

The sedimentary environments predominant in North Germany and Denmark during the Pleistocene were considerably different. Here, practically all Pleistocene deposits were supplied directly or indirectly by the Scandinavian inland ice. However, recent studies in the Hamburg area
(Ehlers 1978a, b) tend to show that even under these conditions the Dutch type of fine gravel analyses supplies valuable stratigraphic information. The present paper reviews these results and reports on an attempt to apply the method on Danish Weichselian deposits, particularly at Ristinge Klint (fig. 1), where three different Weichselian till strata are found.

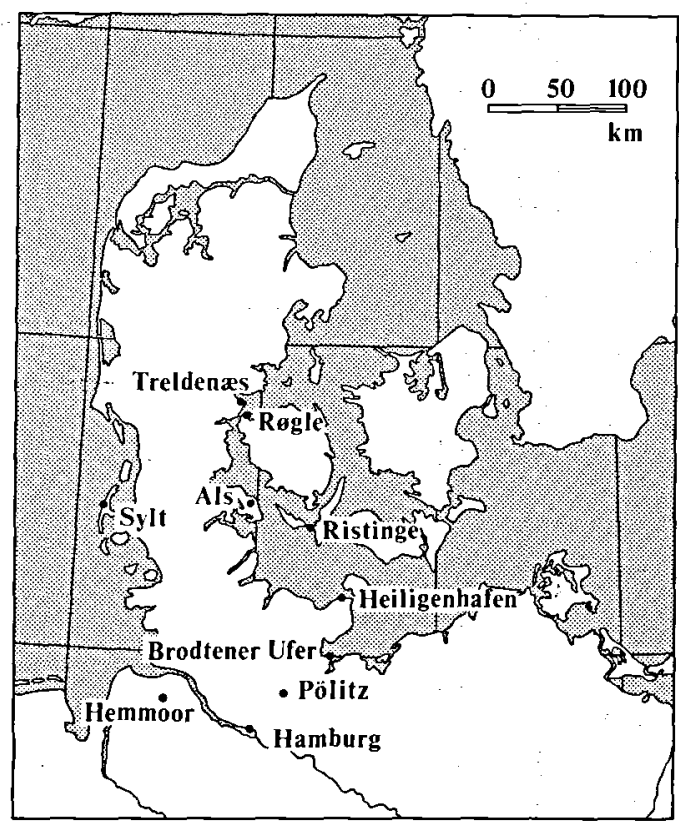

Fig. 1: Location map 
$w$
un
$\Xi$
3
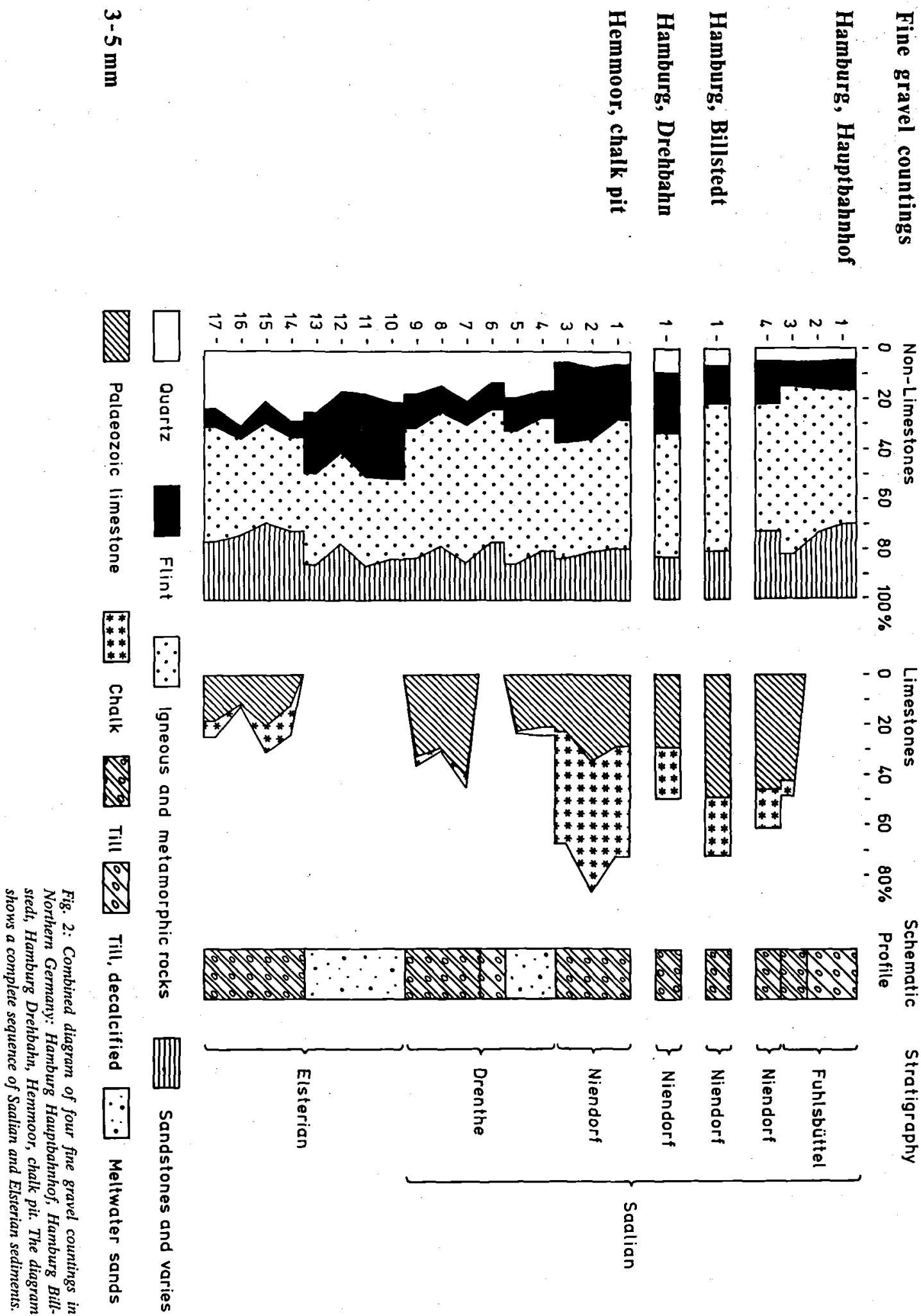

围

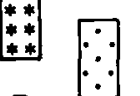

旁

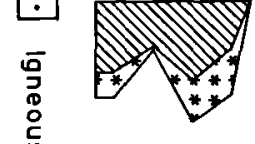

(1)

号

글

马्コ

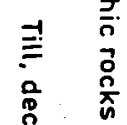
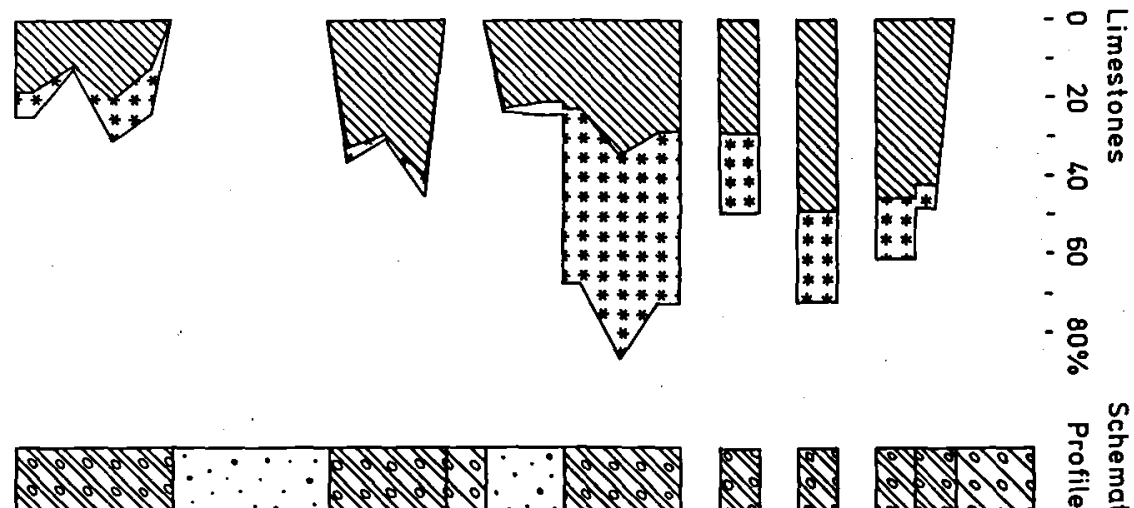

-
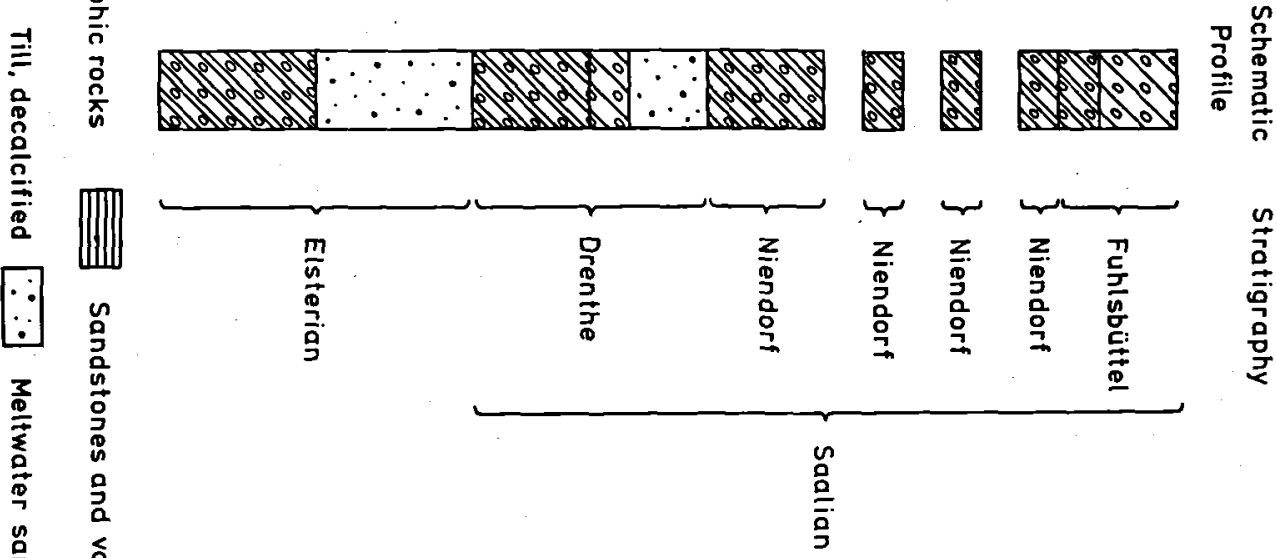
Fine gravel analyses from the Hamburg area

As shown by Ehlers (1978a, b) deposits from the Elsterian glaciation and from three Saalian ice advances can be distinguished in the Greater Hamburg area (table 1) by means of fine gravel analyses. The results are shown i fig. 2 which is a combined diagram of four exposures.

Deposits from the Elsterian glaciation generally contain a high proportion of quartz, obviously derived from underlying Tertiary quartz sands. The Elsterian basal till is frequently blackish-grey in colour due to a high content of lignite originating from Tertiary sediments (H.-C. Höfle, personal information).

Deposits from the Drenthe advance of the Saalian glaciation also show a relatively high quartz content, but a higher amount of flint than the Elsterian deposits. It is possible that areas with high-lying chalk were freed of their Tertiary cover during this advance. The source areas are probably to be found in the Kattegat or on the Danish islands. Till fabric measurements (Ehlers 1975) show that the ice of the Drenthe advance reached the Hamburg area from a northerly direction.

The deposits from the second advance of the Saalian glaciation, the Niendorf advance, differ quite clearly from those of the preceding Drenthe advance. They are rich in flint and chalk and contain less quartz (generally less than 12\%). This advance came to the Hamburg area from a northeasterly direction. It obviously passed between Møn and Rügen.

\section{Table 1 .}

Pleistocene stratigraphy and tills in the Hamburg region

\begin{tabular}{|c|c|c|}
\hline Stage & & $\begin{array}{c}\text { Number of } \\
\text { tills }\end{array}$ \\
\hline Holocene & & - \\
\hline Weichselian glaciation & & - \\
\hline Eemian & & - \\
\hline Fuhlsbüttel advance & & \\
\hline $\begin{array}{l}\text { Niendorf advance } \\
\text { Main-Drenthe advance }\end{array}$ & Saalian glaciation & 3 \\
\hline Holsteinian & & - \\
\hline Elsterian & & 1 \\
\hline pre-Elsterian & (no deposits) & - \\
\hline
\end{tabular}

Pliocene
Deposits from the third Saalian advance, the Fuhlsbüttel advance, usually contain less quartz and small amounts of flint only. There are, however, a number of exceptions - probably due to the fact that material from the preceding advance has been much reworked. Some reworking can be found in almost all Pleistocene deposits, but it rarely causes a complete »levelling " of the fine gravel composition in successive tills. The reason for this is probably the different advance directions of the inland ice. The Fuhlsbüttel advance came from due East to the Hamburg area reaching not far west of Hamburg.

These results from the Hamburg area, particularly those concerning the three Saalian advances may be of interest for comparisons with the pre-Weichselian drift of the "hill-islands « (Bakkeøer) of Southwestern Jutland.

\section{Fine gravel analyses of Weichselian deposits}

The Weichselian advances did not reach the Hamburg area. In Schleswig-Holstein it is difficult to make a morphological sub-division of the Weichselian glaciation, but Stephan (1977) differentiates stratigraphically between five different ice advances, which are not all of the same importance. In Denmark a differentiation between 3 different advances can be made (cf. Berthelsen 1973, 1978, Petersen \& Buch 1974, Sjørring 1977).

In order to obtain some data on the fine gravel composition of the Weichselian drift, fine gravel analyses were made in Schleswig-Holstein at Brodtener Ufer, at Heiligenhafener Ufer and at Pölitz near Bad Oldesloe. With the help of S. Sjørring, several samples were collected on Als, Denmark. Judging from preliminary analyses of these samples it appears that the upper and the lower Weichselian till have a very low quartz content (below 5\%) and a low flint content (less than $15 \%$ ) and are mutually indistinguishable. The middle Weichselian till, on the other hand, contains a high proportion of flint (up to $30 \%$ ).

In order to see if these first promising results could stand a further test, a more complete Weichselian profile, i.e. that of Ristinge Klint was studied. 


\section{Till stratigraphy of the Ristinge Klint section}

The coastal section at Ristinge Klint has become a classic locality for Weichselian stratigraphy due to the studies of Madsen (1916) and Rosenkrantz (1944). More recent studies (Berthelsen 1973, and personal information supplied by $A$. Berthelsen and S. Sjørring) have furthermore shown that the post-Eemian sequence comprises not only two but three till strata (fig. 3 ). In both the western and eastern ends of the section, an uppermost till discordantly overlies the previously described »thin « and »thick « tills in the dislocated floes. At the western end of the section a glacial pavement was found at the base of the uppermost basal till with striation indicating its southeastern provenance. Since this direction concurs with the ice-push determined from the fold axes and the general dip direction of the beds in the floes, the uppermost, discordant till was referred to the advance that caused the dislocations - and overrode them.

In order to further investigate the origin of the discordant till which was less than a few metres thick, the present author has carried out a till fabric analysis where it is exposed at the east end of the section. As shown in fig. 4 the fabric has a clear maximum at $125^{\circ}$. Judging from the com-

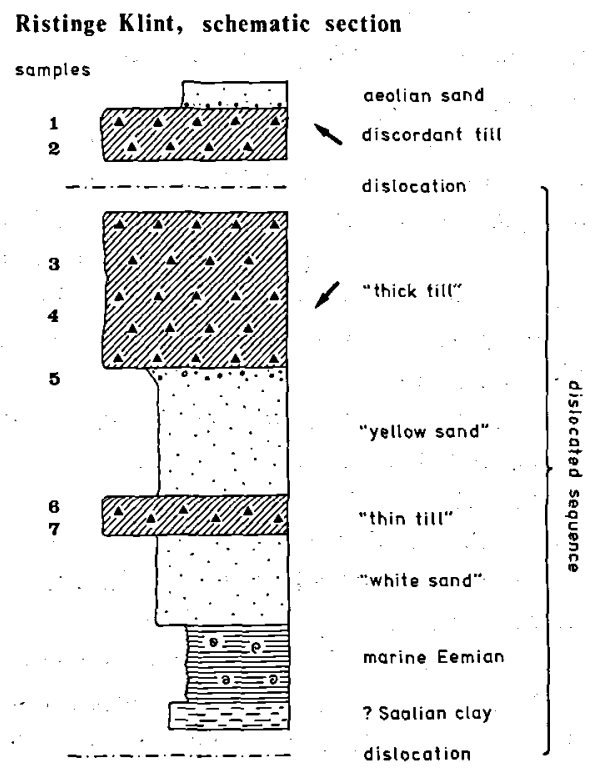

Fig. 3: Ristinge Klint, schematic section, drawn by A. Berthelsen

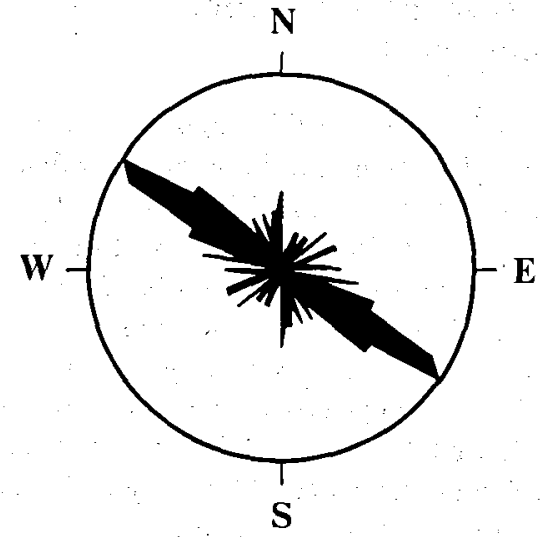

Fig. 4: Fabric diagram of the uppermost till at Ristinge Klint (100 measurements; the circle indicates $10 \%$ ).

bined evidence of glacial-tectonics, the striations on the western pavement and the fabric analysis, its lodgment till nature may be taken for granted and an origin as flow till may be discarded.

The discordant till in Ristinge Klint is to be classed with the Young Baltic advance of southeastern Denmark (Berthelsen 1973, 1978, Sjørring 1977 , Petersen 1978). This advance reached the East Jutlandic ice border line in Denmark and is probably identical with Stephan's (1971) and Seifert's (1954) Fehmarn advance.

The youngest but one till in Ristinge Klint (i.e. the »thick till «) is correlated with the Main Weichselian advance, coming from northeastern directions and reaching the Main Stationary Line in Mid-Jutland. The oldest Weichselian till (the »thin till «) at Ristinge is to be classed with the Old Baltic advance which just like the Young Baltic advance approached southeast Denmark via the Baltic route (Berthelsen 1973, 1978, Sjørring 1977, Petersen 1978).

For the purpose of fine gravel analysis, 7 samples were taken from the Ristinge Klint section: samples 1 and 2 from the discordant till, samples 3 and 4 from the dislocated "thick « till, sample 5 from a layer of gravelly sand directly beneath the »thick « till, and samples 6 and 7 from the lower "thin" till. In order to secure sufficient material for fine gravel analyses of the basal tills, around 5 $\mathrm{kg}$ samples were collected. From gravelly sand, samples of around $1 \mathrm{~kg}$ each proved sufficient.

Granulometric analyses were made from the till samples (fig. 5) but the differences between the 6 samples were very slight indeed. Even if the 


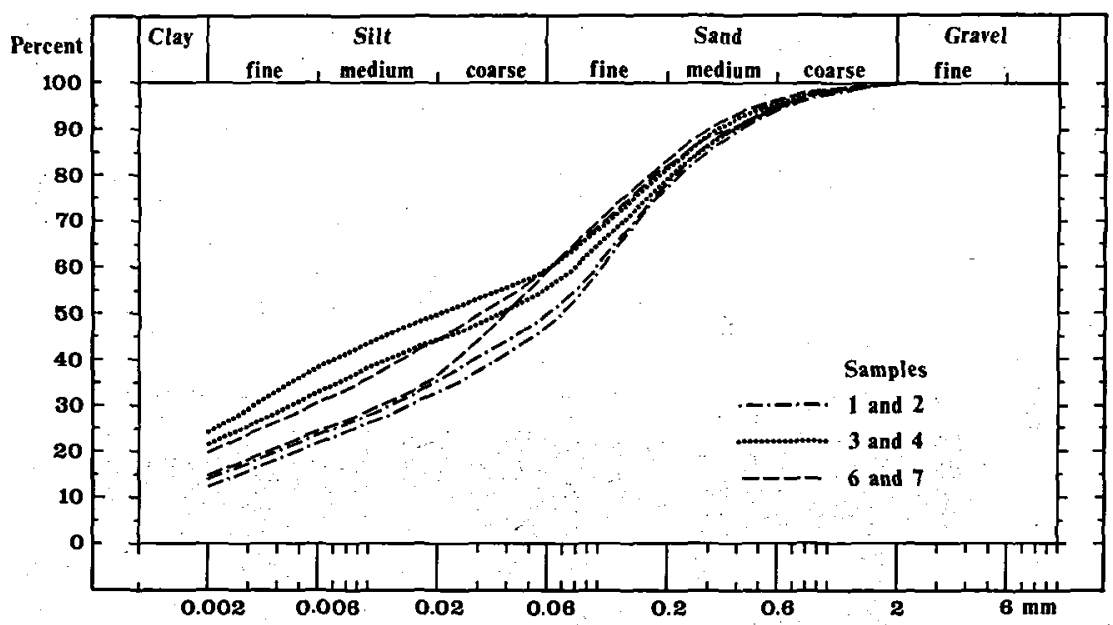

Fig. 5: Grain size distribution of the three tills of Ristinge Klint

discordant till was found to be the sandiest, the middle one the most clay-rich of the three till strata, the results are far from being as conclusive as those of the fine gravel analyses.

\section{Discussion of the method}

A fine gravel analysis comprises identification and counting of at least 300 granules per sample. In the diagrams (fig. 2 and fig. 6) the non-limestones are depicted collectively as $100 \%$. The limestones are depicted separately in order to be able to compare fresh and decalcified samples. Within the Weichselian tills where almost all of the samples contain chalk, this distinction is relatively unimportant, but where samples from older glaciations are compared, this procedure is extremely valuable. About half of the examined more than 300 samples from the Hamburg area were decalcified (as an example see fig. 2).

Among the limestones, Palaeozoic and Cretaceous limestones are differentiated and the counts then expressed as a \% of the non-limestones (if a sample consists of 100 non-limestones and 30 limestones, it contains $30 \%$ limestone according to this method). At times it is useful to count red Palaeozoic limestones on their own. Especially in the Elsterian deposits the red Palaeozoic limestones appear in a far higher concentration than in the younger drift.
In the non-limestones quartz, flint, "igneous rocks $\ll$ and sediments are differentiated. Quartz is naturally rarely found in Weichselian sediments. (Note that quartz grains, which contain traces of feldspar, are counted as »igneous rocks " and that the same is true of feldspar grains).

A further division of the igneous proportion could be attempted but is hardly advisable because the different rock types are difficult to tell apart when the particles are so small. Moreover most easily recognizable rocks (e.g. basalt) occur in too small a concentration. Metamorphic rocks are included in the signeous rocks $\ll$.

There is not much point in making a division among the sediment granules. Glauconitic sandstone or red quartzitic sandstone are easily told apart but they mostly form less than $1 \%$ of the total non-limestones and therefore cannot be statistically registered.

In more recent gravel analysis studies in Denmark the fractions 1.41-6 mm (Bahnson 1973) and 2-4 or 4-6 mm (Petersen 1973, Petersen \& Buch 1974, Petersen \& Konradi 1974) were counted, while earlier the fraction $6-60 \mathrm{~mm}$ was studied (Ussing \& Madsen 1897). Such counts are not easily comparable with each other as the different rock types are represented in different ratios in different fractions (Petersen 1973). Flint, for example, is to be found far more frequently in the coarser fractions than in the finer ones. On the other hand, quartz is practically confined to 


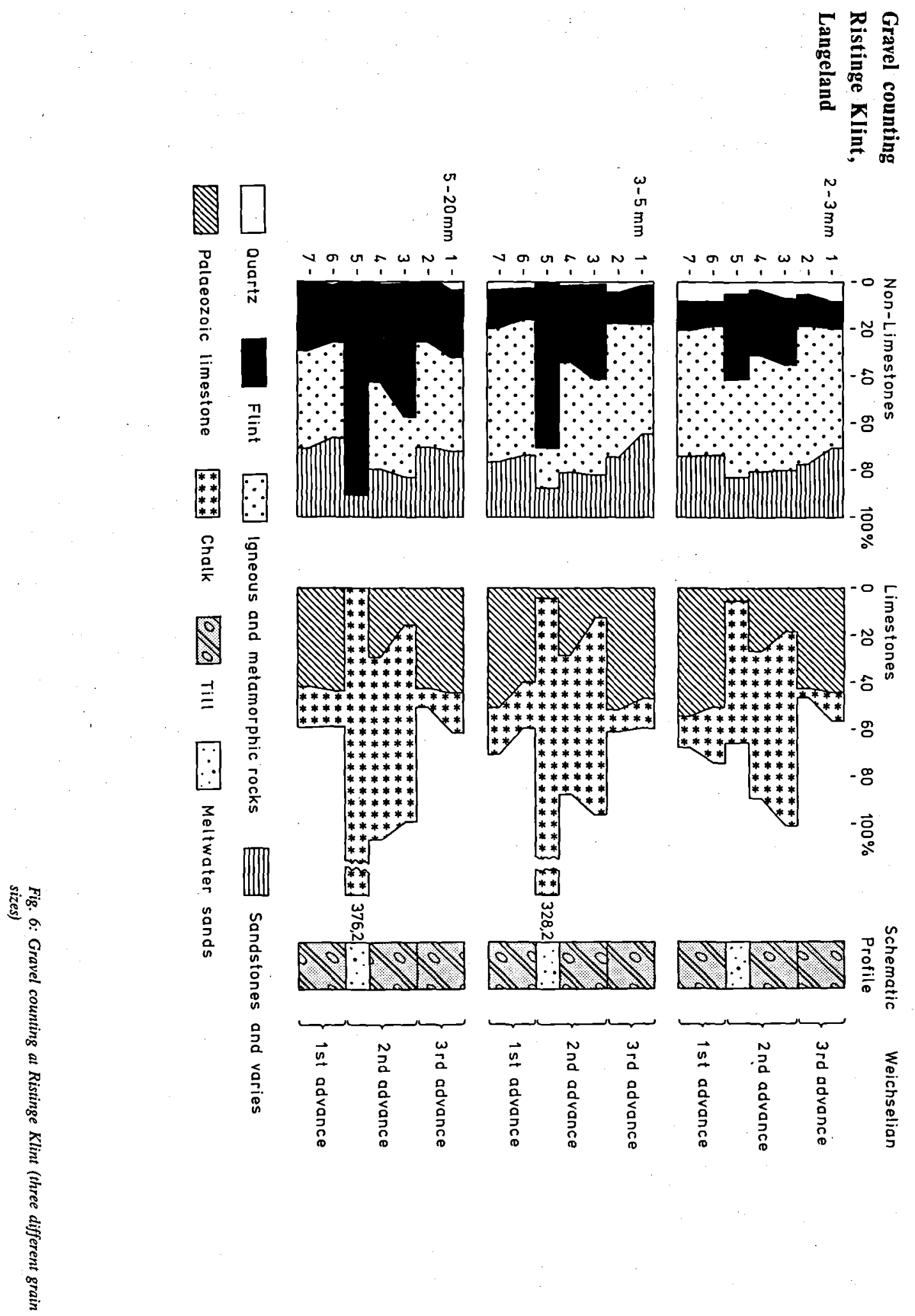


fractions under $5 \mathrm{~mm}$. The igneous proportion diminishes in favour of flint in the coarse fractions (see also Gry 1974).

In order to illustrate the influence of grain size, counts of three different fractions were made on the samples from Ristinge Klint. Apart from the »normal count of fraction 3-5 mm after the Dutch method, the fractions $2-3 \mathrm{~mm}$ and 5-20 $\mathrm{mm}$ were analysed as well (fig. 6).

Sample 5 from the meltwater sand just below the »thick « till deviates from the general trend. In the fraction $2-3 \mathrm{~mm}$ this sample looks very similar to samples 3 and 4 from the overlying sthick " till. This sand is probably an early outwash sand from the ice advance that deposited the till immediately above the gravelly sand layer. Further below the till the fluvioglacial deposits are too fine-grained to be analysed by this method. In the fraction 3-5 $\mathrm{mm}$ the proportion of flint and chalk gravels in sample 5 becomes enormous; in the fraction 5-20 mm igneous rocks and Palaeozoic limestone take over completely from flint and Cretaceous chalks. Until now nothing similar has been found in the meltwater sands in the Hamburg area. Normally the fine gravel analyses of meltwater sands agree with those of the corresponding basal till (e.g. the "Drenthe part in fig. 2).

From fig. 7 it can be seen that analyses of all three fractions $(2-3,3-5$ and $5-20 \mathrm{~mm})$ are suitable to characterize and distinguish the sampled units. In pre-Weichselian tills this is not always the case. There the fraction $5-20 \mathrm{~mm}$ is of practically no value as the proportion of quartz is almost nil and it is just this quartz content which is important in telling the older sediments apart (see fig. 2). The fraction $2-3 \mathrm{~mm}$ isn't very suitable either, since the flint content becomes greatly reduced and this is the second most important factor in distinguishing the deposits. Consequently the fraction 3-5 $\mathrm{mm}$ may be recommended:

\section{Discussion of the results}

The preliminary results from Als and Heiligenhafener Ufer suggested that both the Old and the Young Baltic tills would be practically identical in composition and that only the middle basal till could be identified due to its higher flint and chalk content. The fine gravel analyses carried out on the samples from Ristinge Klint confirm these expectations, but show all the same that it is meaningful to apply this method to Weichselian drift deposits. However, a few points must be considered:

1. Gravel analysis cannot act as a substitute for glacialtectonic and till fabric measurements or studies of the foraminifera content; it can only help to complete the picture. In the study of samples from drillings fine gravel analysis may be the only method that can give hints as to the stratigraphic position of the sampled strata.

2 . The method is not restricted to till samples. Meltwater sands or coarse-grained Tertiary sands can be analysed as well, if they only contain enough granules.

3. The composition of the fine gravel fraction can be affected by local factors, such as contami-

\section{Gravel counting.}

Ristinge Klint

Igneous and metamorphic rocks
Sandstones and varies
Limestone, palaeozoic
Limestone
Flint
Tertiary concretion
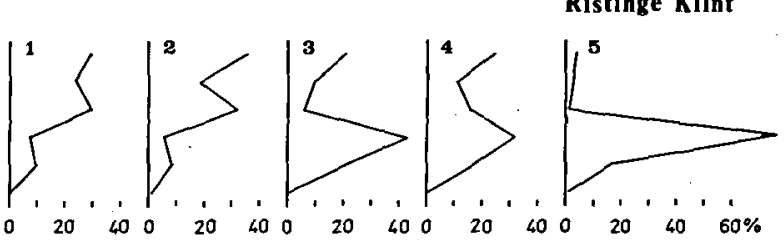

Igneous and metamorphic rocks Sandstones and varies Limestone, patcoozoic Limestone Flint

Tertiary concretion

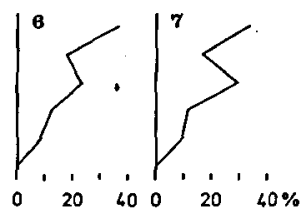

3-5 mm

Fig. 7: Fine gravel counting of the fraction 3-5 $\mathrm{mm}$ at Ristinge Klint, drawn after the method of Petersen 1974 (in Petersen \& Konradi 1974). 
nation from older strata. Therefore attempts to correlate over great distances should only be done with a maximum of care and should not be based on fine gravel analyses alone - unless all other methods (cf. pt. 1) cannot be applied.

4. Individual samples should not be interpreted on their own. It is better to study a profile comprising several samples. As with pollen analyses the most important facts come to light only after the examination of a sequence of different strata.

The way in which the results of the analyses are presented, may be different in different countries. In fig. 7 the results of the Ristinge Klint countings are calculated and illustrated in the Danish way (after Petersen 1974 in Petersen \& Konradi 1974). It depends on each author, which type of illustration he thinks best fitted for his purposes.

Acknowledgements. The author wants to thank Dr. A. Berthelsen and Dr. S. Sjørring, København for their valuable guidance, comments and suggestions throughout this study. Thanks are due to G. and E. Gaumnitz who kindly translated the manuscript into English.

\section{Dansk sammendrag}

Den hollandske fingrus analyse anvendt på Ristinge Klint.

Den hollandske fingrus analyse består af en petrografisk undersøgelse og opdeling af mindst 300 partikler i fraktionen 3-5 mm. Metoden kan anvendes både på moræne- og smeltevandsaflejringer, men lader sig også gennemføre på andre sedimentære enheder, forudsat de indeholder tilstrækkeligt materiale i fraktionen 3-5 mm.

Ved analysen opdeles partiklerne $i$ hovedgrupperne kvarts, flint, grundfjeldsbjergarter (i videste forstand) og kalkfrie sedimentære bjergarter. Disse fire grupper danner tilsammen hoveddiagrammet (fig. 2), og skal for hver talling bestå af mindst 300 korn. Såfremt prøven også indeholder kalkbjergarter opdeles disse i Palæozoiske og Kretasiske kalksten, og disse to grupper afbildes særskilt ved siden af hoveddiagrammet (fig. 2 og 6).

Fordelingen af bjergartstyper angives $i$ procent $\mathbf{i}$ hoveddiagrammet, og summen af de fire hovedkomponenter er det tal, der også er grundlag for udregningen af kalkbjergarternes andel; er der således $1000 \mathrm{korn}$, $i$ en tælling $i$ hoveddiagrammet, anføres 300 kalksten som $30 \%$. På denne måde kan kalkstenene udgøre flere hundrede procent (se fig. 6).

Den hollandske fingrus analyse har fortrinsvis været anvendt i Holland og Nordtyskland på glaciale sedimenter af praWeichsel alder. Aflejringer fra de enkelte isfremstød (tabel 1) lader sig tydeligt adskille også ved anvendelsen af fingrus analysen (fig. 2). Moræneaflejringer fra Elster er således karakteriseret af meget kvarts og lidt flint. Moræneaflejringer fra Saale nedisningerne (Drenthe, Niendorf og Fuhlsbüttel, delvis lokalnavne for formationerne i Hamburg området) kan let adskilles, idet Drenthe indeholder omtrent lige meget kvarts og flint, medens Niendorf indeholder 2-3 gange så meget flint som kvarts. Fuhlsbüttel formationen er lidt vanskeligere at identificere og udviser lidt større variation (ofte på grund af opblanding af aldre materiale), men normalt indeholder Fuhlsbüttel kun en ringe mængde kvarts og flint.

$P a ̊$ grund af metodens anvendelighed i pra-Weichsel aflejringerne var det narliggende at undersøge, om Weichsel istidens formationer kunne adskilles på tilsvarende måde. Til denne undersøgelse valgtes Ristinge Klint, idet de tre moræneformationer $i$ klinten har en kendt stratigrafisk placering (fig. 3 ). Syv prøver er blevet analyseret, heraf seks fra moræneformationerne.

Tællinger $\mathrm{j}$ fraktionen 3-5 mm viser, at det er muligt at opdele morænerne i to grupper, hvor den diskordante moræne og den tynde moræne stort set har samme petrografiske indhold, nemlig et ubetydeligt indhold af kvarts og kun lidt flint (fig. 6). Den anden gruppe omfatter prøverne fra den tykke moræene og det underliggende smeltevandssand. I denne gruppe er der heller ikke ret meget kvarts, men til gengald er indholdcet af flint ret stort.

Opdelingen i to grupper er ikke forbavsende, idet både den tynde morane og den diskordante moræne er af baltisk oprindelse. Som yderligere kontrol er der foretaget en stenorienteringsmåling (fig. 4) $\mathrm{i}$ den diskordante moræne. Målingen viser en nøje overensstemmelse mellem stenenes foretrukne retning og den bevægelsesretning, der har frembragt deformationerne af lagfølgen under den diskordante moræne. I den vestlige del af Ristinge Klint findes ved basis af den diskordante morane også en isskuret brolægning, og skurestriberetningen viser også en bevægelsesretning fra sydøst. Den diskordante moræne er derfor en bundmoræne og er aflejret af den is, der frembragte dislokationerne i Ristinge Klint.

Moræneprøvernes granulometriske sammensatning er blevet bestemt (fig. 5). Bortset fra, at den diskordante moræne er lidt mere sandet end de øvrige, er det ikke muligt, at adskille morænerne på grundlag af kornstørrelsesfordelingen.

Der er tidligere udført en lang række stentællinger i danske moræneaflejringer, men $i$ noget forskellige fraktioner. Ved denne undersøgelse af morænerne i Ristinge Klint er fraktionerne 2-3 mm og 5-20 mm også talt. Af fig. 6 fremgår det, at moranerne kan opdeles i 2 grupper, uanset hvilken fraktion, der er talt, men det er ikke muligt at korrellere tallinger, der er udført i forskellige fraktioner. Det ses tydeligt, at kvarts stort set mangler i fraktionen større end $5 \mathrm{~mm}$, og i fraktioner mindre end $3 \mathrm{~mm}$ er indholdet af fint blevet stærkt reduceret. For at muliggøre en vurdering af metoden er tallingerne fra Ristinge Klint afbildet i fig 7 efter den af Petersen (1974) i Petersen \& Konradi (1974) anvendte form.

Som andre stentællingsmetoder, er den hollandske fingrus analyse ikke egnet til at træde $i$ stedet for andre geologiske undersogelser (tektonik, stenorientering, indhold af omlejrede foraminiferer osv.), men metoden kan bidrage med yderligere oplysninger om det geologiske hændelsesforløb. Det anbefales, at prøverne udtages i serier i vertikale profiler (i princip, som vel pollen analyse), for derved også at bringe oplysninger om variationen og lokalindblanding. Enkeltprøver fra enkelte lokaliteter kan ikke tillægges samme vægt, som proveserier.

Den hollandske fingrus analyse har den fordel, frem for andre, at resultaterne er uafhængige af, om proverne er kalkholdige eller ej.

\section{References}

Bahnson, H. 1973: Lithological investigations in some Danish boulder-clay profiles. Bull. geol. Inst. Univ. Uppsala N.S. 5: 93-109.

Berthelsen, A. 1973: Weichselian ice advances and drift successions in Denmark. Bull. geol. Inst. Univ. Uppsala N. S. 5: 21-29.

Berthelsen, A. 1978: The methodology of kineto-stratigraphy as applied to glacial geology. Bull. geol. Soc. Denmark, 27 Special issue, 25-38. 
Ehlers, J. 1975: Neue Untersuchungen zur Entstehung der Harburger Berge. Harburger Jahrbuch 14: 7-49.

Ehlers, J. 1978 a: Die quartäre Morphogenese der Harburger Berge und ihrer Umgebung. Mitt. Geogr. Ges. Hamburg 68: $181 \mathrm{pp}$.

Ehlers, J. 1978 b: Feinkieszählungen nach der niederländischen Methode im Hamburger Raum. Der Geschiebesammler 12, 2/3: 47-64.

Gry, H. 1974: Ledeblokkes kornstørrelsesforhold og transportmåde. Dansk geol. Foren. Arsskrift. 1973: 140-151.

Maareleveld, G. C. 1956: Grindhoudende midden-pleistocene sedimenten. Medd. Geol. Sticht. Ser. C-VI, 6: 105 pp.

Madsen, V. 1916: Ristinge Klint. Danm. geol. Unders. rk 4, 1, 2: $32 \mathrm{pp}$.

Petersen, K. S. 1973: Tills in dislocated drift deposits on the Røsnaes Peninsula, Northwestern Sjaelland, Denmark. Bull. geol. Inst. Univ. Uppsala N. S. 5: 41-49.

Petersen, K. S. \& Buch, A. 1974: Dislocated tills with Paleogene and Pleistocene marine beds. Tectonics, lithology, macro- and microfossils. Danm. geol. Unders., Arbog 1973: 63-91.

Petersen, K. S. \& Konradi, P. 1974: Lithologisk og Palæontologisk beskrivelse af profiler i Kvartæret på Sjalland. Dansk geol. Foren., Arsskr. 1973: 47-56.

Rosenkrantz, A. 1944: Nye Bidrag til Forstaaelsen af Ristinge Klints Opbygning. Medd. Dansk geol. Foren. 10,431-435.

Seifert, G. 1954: Das mikroskopische Korngefüge des Geschiebemergels als Abbild der Eisbewegung, zugleich Geschichte des Eisabbaues in Fehmarn, Ost-Wagrien und im Dänischen Wohld. Meyniana 2: 124-190.
Sjørring, S. 1977: The glacial stratigraphy of the island of Als, southern Denmark. Z. Geomorph. N. F., Suppl.-Bd. 27: 1-11.

Stephan, H.-J. 1971: Glacialgeologische Untersuchungen im Raum Heiligenhafen (Ostholstein). Meyniana 21: 41-66.

Ussing, N. V. \& Madsen, V. 1897: Kortbladet Hindsholm. Danm. geol. Unders. rk 1, 2: 87 pp.

Zandstra, J. G. 1959: Grindassociaties in het Pleistoceen van Noord-Nederland: een sammenvatting van de voorlopige resultaten van grindonderzoek, in het bijzonder van het Onder- en Midden-Pleistoceen. Geol. en Mijnbouw N. S. 21: 254-272.

Zandstra, J. G. 1971: Geologisch onderzoek in de stuwwal van de oostelijke Veluwe bij Hattem en Wapenveld. Meded. Rijks Geol. Dienst, N. S. 22: 215-259.

Zandstra, J. G. 1975: Sediment-petrological investigations of a boring and an excavation at Peelo (Northern Netherlands). Meded. Rijks Geol. Dienst, N. S. 26, 1: 1-15.

Zandstra, J. G. 1976: Sedimentpetrographische Untersuchungen des Geschiebelehms von Emmerschans (Drenthe, Niederlande) mit Bemerkungen über eine Typeneinteilung der Saale-Grundmoräne. Eiszeitalter $u$. Gegenwart 27: $30-52$.

Zandstra, J. G. 1977: Geologische opbouw van het Pleistoceen. In: Staalduinen (editor): Geologisch onderzoek van het Nederlandse Waddengebiet: 37-58, Haarlem.

Zandstra, J. G. 1978: Einführung in die Feinkiesanalyse. Der Geschiebesammler 12, 2/3: 21-38. 